\title{
Giant cell arteritis presenting as subclavian artery occlusion. A report of two cases
}

\author{
D. R. SWINSON \\ M.B., B.S., M.R.C.P. \\ C. J. GoodwILL \\ M.B., B.S., M.R.C.P. \\ I. C. TALBOT \\ M.B., B.S., M.R.C.Path. \\ Department of Rheumatology and Rehabilitation and Department of Morbid Anatomy, \\ King's College Hospital, London
}

\begin{abstract}
Summary
Two patients with the aortic arch syndrome and biopsy-proved but asymptomatic temporal giant cell arteritis are described. Corticosteroid treatment was followed by the return of peripheral pulsation in these two patients after an interval of a few months. A review of the literature suggests that of patients where giant cell arteritis causes subclavian obstruction there is an undue predominance of women, compared to the sex ratio found in giant cell arteritis overall.
\end{abstract}

THE symptomatology and morbidity of giant cell arteritis is often due to arterial occlusion. Despite the alternative localizing names of temporal or cranial arteritis, it has been long appreciated that the disease is often widespread in the arterial tree (Cardell et al., 1946). Involvement of the subclavian vessels is commonly found at post-mortem: for example, in sixteen post-mortem examinations of patients with giant cell arteritis, there was subclavian involvement in nine (Cardell et al., 1968). Although reported (Pollock, Blennerhassett and Clarke, 1973; Rolland et al., 1973; Thompson, Simmons and Smith, 1971; Hamilton, Shelley and Tumulty, 1971), ischaemic symptoms from such involvement are said to be rare (Meadows, 1966) and it is therefore considered that two patients who presented with intermittent claudication of the arms would be of interest.

\section{Case No. 1}

In November, 1971, a 74-year-old woman developed aching shoulder pains which radiated to her neck or down her arms and were brought on by exercise and hot baths and were relieved by rest. She was otherwise well.

After about a year, she developed rest pain and stiffness in her shoulders, worse in the morning, and in the winter of 1972/1973 Raynaud's phenomenon of both hands.

Correspondence: Dr D. R. Swinson, Consultant Rheumatologist, Wrightington Hospital, $\mathrm{Nr}$ Wigan, Lancs.
In June, 1973, there were absent pulses in her arms, distal to the subclavian pulses and a bruit could be heard over the left subclavian pulse. An arch aortogram showed occlusion of both subclavian arteries (Fig. 1).

In November, 1973, she was admitted to King's College Hospital for further investigations. Apart

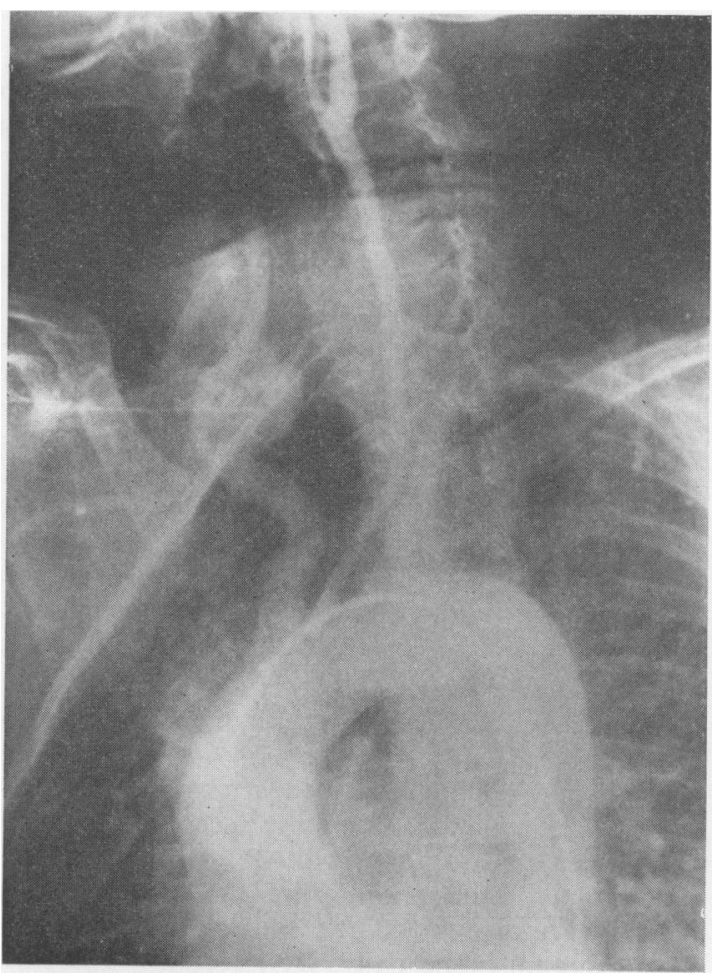

Fig. 1. Arch aortogram of patient no. 1-this shows bilateral occlusion of both subclavian arteries with dilatation of the first part of the right subclavian artery and non-visualization of the right vertebral artery. 


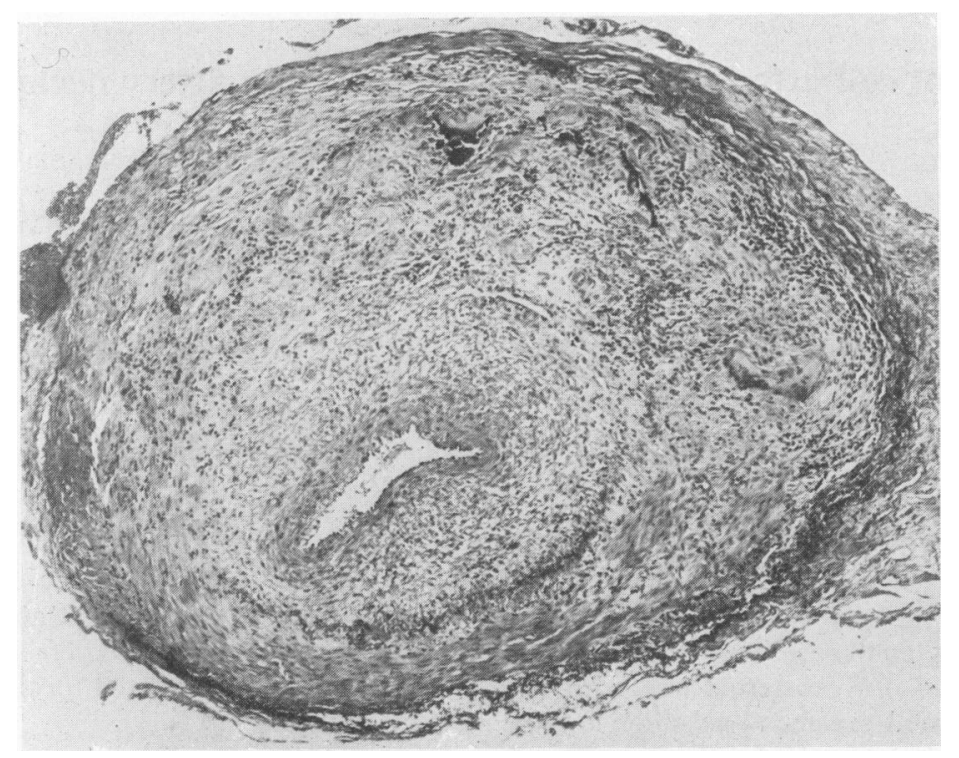

FIG. 2. Temporal artery showing features of giant cell arteritis with severe destruction of medial muscle and internal elastic lamina and a marked chronic inflammatory cell infiltrate including multinucleate giant cells. Elastic van Gieson stain, $\times 64$.

from the above findings, the history revealed recent occipital headaches and a past history of angina 4 years previously which had spontaneously improved.

When examined she was apyrexial. Both carotid and temporal pulses were palpable but her subclavian, brachial, ulnar and radial pulses were absent. A flow murmur could be heard over her supraclavicular fossae. The left dorsalis pedis and posterior tibial pulses were absent but apart from this, the examination was normal. Her ESR was $41 \mathrm{~mm}$ (Westergren), plasma urea, electrolytes, random blood sugar, calcium, inorganic phosphorus, uric acid, liver function tests and serum proteins were within normal limits. Search for LE cells was negative and auto-antibody screen and WR were negative. ECG showed non-specific $T$-wave changes. Chest X-ray showed normal heart and lungs and aortic calcification. X-rays of the spine showed osteoporosis and degenerative changes. A biopsy of the superficial temporal artery in November, 1973, showed features of giant cell arteritis (Fig. 2). A diagnosis of aortic arch syndrome secondary to giant cell arteritis was made and $40 \mathrm{mg}$ prednisolone daily started. Her shoulder pain and stiffness soon decreased and 3 weeks later she was discharged on $20 \mathrm{mg}$ prednisolone daily. By February, 1974, her shoulder pain and stiffness were absent but her arm claudication remained (ESR was $9 \mathrm{~mm}$ ). The prednisolone was reduced to $15 \mathrm{mg}$ daily. In July, 1974, her right radial pulse became palpable but she again developed right sided headaches, and in September the prednisolone was increased to $20 \mathrm{mg}$ daily again because the headaches persisted despite her ESR being $7 \mathrm{~mm}$.

\section{Case no. 2}

A 62-year-old woman was well until she developed right sided frontal headaches in August, 1973. Three weeks later, she noticed palpitation and shortness of breath on exertion and was admitted to hospital. When examined one month later, she was depressed and tense. There was a persistent tachycardia of 90-100 and during admission her blood pressure in the arms varied between 170/100 and $120 / 70 \mathrm{mmHg}$. There was no sign of cardiac failure and she was clinically euthyroid and apyrexial. Investigations revealed abnormal liver function tests -bilirubin was $2 \cdot 1 \mathrm{mg} / 100 \mathrm{ml}$, alkaline phosphatase was 167 i.u./l and aspartate amino transferase 75 i.u./l. An ECG showed right axis deviation. Blood count, plasma urea and electrolytes, calcium, phosphorus, uric acid and total protein were normal. T4 was $81 \mathrm{mg} / \mathrm{ml}$ (normal 40-110 ng/ml). ESR was not done. She was considered to have a depressive illness. Her symptoms improved in hospital and she was discharged for follow-up in psychiatric out-patients. By November, 1973, her headaches and shortness of breath returned but she continued at work. By the end of November, she had developed pain in her arms. The pain was described as tight, 
occurred on exercise and was absent at rest. It was associated with whiteness of the left fingers on exposure to cold. In January, 1974, palpation of her pulses showed normal subclavian pulses but absent axillary, brachial and ulnar pulses, her radial pulses were barely perceptible and her blood pressure was unobtainable in each arm. All leg pulses were present but there was a right femoral bruit. Temporal pulses were normal. There were no bruits in her shoulders, neck or arms.

At this time, her ESR was $38 \mathrm{~mm}$ and liver function tests had returned to normal apart from an alkaline phosphatase slightly raised at 108 i.u./l. Autoantibody screen was negative and ECG showed no abnormality. She was reluctant to undergo temporal artery biopsy but in February, 1974, a right sided biopsy was obtained which showed giant cell arteritis. A week later a repeat ESR was only $16 \mathrm{~mm}$. She was prescribed $15 \mathrm{mg}$ prednisolone daily. The relatively low dose was used because her condition had appeared to be improving for about 4 weeks and her ESR was falling. By June, 1974, some 9 months after the start of her illness, her brachial pulses had returned although she still suffers some claudication.

\section{Discussion}

Both these patients had giant cell arteritis on temporal artery biopsy. However, the presenting feature in each case was intermittent claudication of the arms with Raynaud's phenomenon. This could be confused with polymyalgia rheumatica and patient no. 1 quite clearly had both types of pain, the myalgia occurring about a year after the claudication began, and responding dramatically to corticosteroids, in contrast to the claudication which has only gradually improved in both patients Obstruction of major vessels arising from the arch of the aorta is often known as the aortic arch syndrome and the differential diagnosis includes atherosclerosis, thoracic outlet syndrome, giant cell arteritis and rarely other collagen-vascular diseases. Although atheroma is common at this age, the symmetrical loss of pulses (Gilmour, 1941) and a raised ESR make an arteritis likely. The final diagnosis rests on biopsy, although temporal arteriography may be a useful adjunct (Hunder et al., 1972) but this was not used in these two cases. The differential diagnosis from Takiyashu's arteritis is based almost entirely on age, although giant cell arteritis has been reported in young women (Gilmour et al., 1941) and Takiyashu's arteritis in an older woman (Alestig and Barr, 1963). The distribution of the arteritis is similar as is the histology, giant cells occurring in the early stages of Takiyashu's disease (Judge et al., 1962) and not. being a feature of long standing giant cell arteritis (Fauchald, Rygvold and Oystese, 1972). In giant cell arteritis overall, however, unlike Takiyashu's disease, there is only a minor predominance of women; of 613 cases from the literature, 254 were male and 359 female (Alestig and Barr, 1963; Bruk, 1967; Cardell and Hanley, 1951; Cook et al., 1946; Gilmour, 1941 ; Hamilton et al., 1971; Hamrin, Jonsson and Landberg, 1964, 1965; Hamrin, Jonsson and Hellsten, 1968; Harrison and Bevan, 1967; Hunder and Sheps, 1967; Jennings, 1938; Paulley and Hughes, 1960; Pollock et al., 1973; Reid, 1957; Rolland et al., 1973: Thompson et al., 1971) and this difference can be largely accounted for by the sex ratios in the older age groups. However, of fifteen cases where the subclavian arteries were definitely involved clinically (Alestig and Barr, 1963; Bruk, 1967; Hamilton et al., 1971; Hamrin et al., 1968; Jennings, 1938; Paulley and Hughes, 1960; Pollock et al., 1973; Reid, 1957; Rolland et al., 1973; Thompson et al., 1971), only two were male, the difference in sex ratio being significant $(P<0.05>0.02)$.

It appears, therefore, that in the aortic arch syndrome due to giant cell arteritis there may be a female predominance as found in classical Takiyashu's arteritis. The similarity and possible identity of the two conditions is further discussed by Hamilton (1971) and Hall (1973). Other features of case no. 1 suggesting a widespread arteritis were a history of angina and occipital headaches and the aortic calcification (Reid, 1957). The illness of patient no. 2 included depression and was also associated with abnormal liver function tests, both of which are manifestations of giant cell arteritis (Paulley and Hughes, 1960; Rolland et al., 1973; Hall and Hargreaves, 1972). By the time of diagnosis, the ESR had fallen to $16 \mathrm{~mm}$ in the first hour without treatment but the biopsy was still unequivocal. Although a raised ESR is usually associated with an active arteritis, cases with only slightly raised or normal ESR are documented (Bruk, 1967; Pollock et al., 1973). If this fall in ESR does represent resolution of her illness it had begun and rccovered in a year, without the use of corticosteroids. There is no doubt that many of the patients with giant cell arteritis did recover before the corticosteroid era, morbidity depending on the arteries involved and whether or not the intima was affected. Judge (1962) describes a 61year-old woman with arteritis and an aortic arch syndrome with arm claudication who partially recovered without steroids (as did the subject of Hutchinson's (1890) original paper on temporal arteritis who recovered completely and lived for many years after). In a review of patients untreated by corticosteroids by Anderson (1947), only seven of fifty-seven died from the effects of the arteritis and the selection involved in the collection of the patients suggested that this was rather a pessimistic proportion. Meadows (1966) estimated that about $50 \%$ of 
TABLE 1

\begin{tabular}{|c|c|c|c|}
\hline Author & $\begin{array}{l}\text { Patient } \\
\text { age (in years) } \\
\text { and sex }\end{array}$ & $\begin{array}{l}\text { Site of arterial } \\
\text { occlusion }\end{array}$ & $\begin{array}{c}\text { Time between start } \\
\text { of steroid treatment } \\
\text { and return of } \\
\text { peripheral pulsation }\end{array}$ \\
\hline $\begin{array}{l}\text { Hunder et al., } 1967 \\
\text { Hunder and Sheps, } 1967 \\
\text { Bruk, } 1967\end{array}$ & $\begin{array}{ll}65 \mathrm{~F} \\
51 \mathrm{~F} \\
67 \mathrm{~F}\end{array}$ & $\begin{array}{l}\text { Subclavian artery } \\
\text { Popliteal artery } \\
\text { Subclavian artery }\end{array}$ & $\begin{array}{r}16 \text { weeks } \\
30 \text { weeks } \\
6 \text { weeks }\end{array}$ \\
\hline
\end{tabular}

the patients would survive relatively unscathed if untreated.

It has been shown by comparing the occurrence of visual failure before and after the availability of steroids that corticosteroid treatment not only ameliorates the symptoms of giant cell arteritis, but can prevent complications (Birkhead, Wagener and Schick, 1957; Russell, 1959).

The time interval between commencement of steroid treatment and the return of palpable arm pulses was 7 months for case 1 and 3 months for case 2 . Table 1 gives the time intervals between the commencement of steroid treatment and the return of peripheral pulses, which are mentioned in the literature. Pollock (1973), Hamilton (1971) and Alestig and Barr (1963), also describe improvement in circulation after steroid treatment but do not give the precise details of the time interval involved. In aortic arch syndrome secondary to giant cell arteritis it seems therefore justifiable to treat with an adequate dose of corticosteroid alone, using immediate surgery only if the ischaemia is threatening life or limb. However, subclavian obstruction from giant cell arteritis has been successfully treated by disobliteration and corticosteroids combined (Thompson et al., 1971; Hamilton et al., 1971) and this would seem appropriate if the ischaemia is severe or not improving within about 7 months.

\section{References}

Alestig, K. \& BARR, J. (1963) Giant cell arteritis-a biopsy study of polymyalgia rheumatica including one case of Takiyashu's disease. Lancet, i, 1228.

ANDERSON, T. (1947) Arteritis temporalis-a symptom of a generalised vascular disease. Acta medica scandinavica, 128, 153.

BirkheAD, N.C., WAgener, H.P. \& Schick, R.M. (1957) Treatment of temporal arteritis with adrenal corticosteroids. Journal of the American Medical Association, 163, 821.

BRUK, M.I. (1967) Articular and vascular manifestations of polymyalgia rheumatica. Annals of the Rheumatic Diseases, 26, 103.

Cardell, B.S. \& Hanley, T. (1951) A fatal case of giant cell or temporal arteritis. Journal of Pathology and Bacteriology, 63, 587.

Cook, W.T., Cloake, P.C.P., Gowan, A.D.T. \& Colbeck, J.C. (1946) Temporal arteritis-a generalised vascular disease. Quarterly Journal of Medicine, New Series, XV, No. $57,47$.
Fauchald, P., Rygvold, O. \& Oystese, B. (1971) Temporal arteritis and polymyalgia rheumatica - clinical and biopsy findings. Annals of Internal Medicine, 77, 845.

GilmouR, V.R. (1941) Giant cell chronic arteritis. Journal of Pathology and Bacteriology, 53, 263.

Hall, G.H. (1973) Giant cell arteritis-an unholy trinity. American Heart Journal. 85, 835.

Hall, G.H. \& Hargreaves, T. (1972) Giant cell arteritis and raised serum alkaline phosphatase levels. Lancet, ii, 48.

Hamilton, C.R., Jr, Shelley, W.M. \& Tumulty, P.A. (1971) Giant cell arteritis. Including temporal arteritis and polymyalgia rheumatica. Medicine, Baltimore, 50, 1.

Hamrin, B., Jonsson, N. \& Hellsten, S. (1968) Polymyalgia arteritica. Further clinical and histopathological studies with a report of six autopsy cases. Annals of the Rheumatic Diseases, 27, 397.

Hamrin, B., Jonsson, N. \& LANDberg, T. (1964) Arteritis in polymyalgia rheumatica. Lancet, i, 397.

HAMrin, B., Jonsson, N. \& LANDberG, T. (1965) Involvemeng of large vessels in polymyalgia arteritica. Lancet, $\mathbf{i}, 1193$.

HarRison, M.J.G. \& BeVAN, A.T. (1967) Early symptoms of temporal arteritis. Lancet, ii, 638.

Hunder, G.G., Baker, H.L., Rhoton, A.L., Sheps, S.G. \& WARD, L.E. (1972) Superficial temporal arterography in patients suspected of having temporal arteritis. Arthritis and Rheumatism, 15, 561.

HuNDER, G.G. \& SHEPS, S.G. (1967) Intermittent claudication and polymyalgia rheumatica (association with panarteritis). Annals of Internal Medicine, 119, 638.

Hunder, G.G., WARD, L.E. \& BurbanK, M.D. (1967) Giant cell arteritis producing an aortic arch syndrome. Annals of Internal Medicine, 66, 578.

HutChinson, J. (1890) Diseases of the arteries-on a peculiar form of thrombotic arteritis of the ages, which is sometimes productive of gangrene. Archives of Surgery. London, $1,323$.

JenNings, G.H. (1938) Arteritis of the temporal vessels. Lancet, i, 424.

Judge, R.D., Currier, R.D., Grace, W.A. \& Figley, M.M. (1962) Takiyashu's arteritis and the aortic arch syndrome. American Journal of Medicine, 32, 379.

Meadows, S.P. (1966) Temporal or giant cell arteritis. Proceedings of the Royal Society of Medicine, 32, 329.

Paulley, J.W. \& Hughes, J.P. (1960) Giant cell arteritis of $\mathcal{N}$ the aged. British Medical Journal, 2, 1562.

Pollock, M., Blennerhassett, J.B. \& Clarke, A.M. (1973) Giant cell arteritis and subclavian steal syndrome. Neurology, 23, 653.

ReID, J.V.O. (1957) Dilation of the aorta due to granulomatous (giant cell) arteritis. British Heart Journal, 19, 206.

Rolland, E., Dickson, J.E., Maldonado, S.S., Sheps, J.A. \& CAIN, J. (1973) Systematic giant cell arteritis with polymyalgia rheumatica. Reversible abnormalities of liver function. Journal of the American Medical Association, 224, No. 11, 1496. 
RusSELl, R.W.R. (1959) Giant cell arteritis-a review of 35 cases. Quarterly Journal of Medicine, XXVIII, No. 112, 471.
Thompson, J.R., Simmons, C.R. \& Smith, C.C. (1971) Polymyalgia arteritica with bilateral subclavian artery occlusive disease. Radiology, 101, 595.

\title{
Pulmonary oedema in meningococcal meningitis
}

\author{
R. J. FranKel \\ M.B., B.Ch., M.R.C.P. \\ E. D. BENNETT \\ M.B., B.S., M.R.C.P. \\ C. D. Borland \\ Medical Unit, St George's Hospital, London SW1X $7 E Z$
}

\begin{abstract}
Summary
Two cases of meningococcal meningitis complicated by pulmonary oedema are described. The pulmonary arterial wedge pressure was raised in the one case studied.

Profound sympathetic over-activity may be the cause of the pulmonary oedema occurring in this situation. If this is so, adrenergic blockade would appear to be a rational approach to therapy.
\end{abstract}

\section{Introduction}

Although pulmonary oedema is a recognized complication of intracranial lesions, it has only rarely been reported in relation to meningococcal meningitis and in none of these cases were any haemodynamic studies performed.

\section{Case report no. 1 .}

A 21-year-old male presented to the casualty department with an extensive rash of sudden onset. This followed a 5-day history of general malaise and a 2-day history of abdominal pain. On examination he was extremely ill but fully conscious. He was cyanosed and an extensive purpuric rash was noted. There was no neck stiffness or localizing neurological signs. Blood pressure was $70 / 40 \mathrm{mmHg}$, pulse rate $120 / \mathrm{min}$, and his extremities were cold and clammy. Investigations: haemoglobin $17 \mathrm{~g} / 100 \mathrm{ml}$, white blood count $5,500 / \mathrm{mm}^{3}$, platelets $15,000 / \mathrm{mm}^{3}$. Gramnegative cocci were seen on the blood film. A diagnosis of meningococcal septicaemia was made, and resuscitative measures were begun. He was given hydrocortisone $200 \mathrm{mg}$, sulphadimidine $2 \mathrm{~g}$, penicillin 6 megaunits. However, his condition rapidly deteriorated. He became very restless and began to

Correspondence: E. D. Bennett, Intensive Therapy Unit, St George's Hospital, Blackshaw Road, London, S.W.17. hyperventilate and cough up large quantities of frothy sputum. Intubation and artificial ventilation failed to improve his condition. Cardiac arrest occurred, and further resuscitation was unsuccessful.

At post-mortem examination there was evidence of basal meningitis but no other neurological abnormality. The lungs showed 'terminal pneumonia' and the heart gross dilatation of the right ventricle. The adrenal glands revealed some haemorrhage and oedema.

\section{Case report no. 2}

A 19-year-old labourer was admitted as an emergency with a 3-hr history of headache, vomiting and pain in the abdomen and legs. He had been well until the onset of this illness, and had no relevant past medical history. On examination he was restless and confused. His temperature was $40^{\circ} \mathrm{C}$ and there was marked neck stiffness. Pulse rate $90 / \mathrm{min}$ and hyperdynamic. Blood pressure $130 / 70 \mathrm{mmHg}$. The cardiovascular and respiratory systems were normal. No focal neurological signs were present, and in particular there was no papilloedema. Investigations: lumbar puncture revealed a pressure greater than $200 \mathrm{~mm}$ (although the patient was restless at the time). Cerebrospinal fluid protein $650 \mathrm{mg} \%$, glucose $31 \mathrm{mg} \%$; microscopy showed neutrophils 10,500/ $\mathrm{mm}^{3}$, red cells $5,500 / \mathrm{mm}^{3}$ but no bacteria. On culture, however, a light growth of Neisseria meningitis was obtained. Haemoglobin $13.9 \mathrm{gm} \%$, white blood count $16,000 / \mathrm{mm}^{3}$ with $69 \%$ neutrophils, $22 \%$ lymphocytes and $7 \%$ monocytes. Urea and electrolytes normal. Treatment was started with $20,000 \mathrm{u}$ intrathecal penicillin, $4 \mathrm{~g}$ sulphadimidine stat. i.m., followed by $2 \mathrm{~g}$ 6-hourly.

Six hours after admission he became increasingly restless and started to scratch and excoriate the skin 